Ann. Biol. anim. Bioch. Biophys., I976, 16 (3), 49I-50г.

\title{
SERUM BINDING OF SOME STEROID HORMONES DURING DEVELOPMENT IN DIFFERENT ANIMAL SPECIES. DISCUSSION ON THE BIOLOGICAL SIGNIFICANCE OF THIS BINDING
}

\author{
E. A. NUNEZ, Claudine BENASSAYAG, Lia SAVU, \\ Geneviève VALLETTE, and M. F. JAYLE \\ Laboratoire associé du C.N.R.S., no 87, \\ U.E.R. Biomédicale des Saints-Pères, \\ 45, rue des Saints-Pères \\ 75270 Paris Cedex 06
}

\section{SUMMARY}

Serum binding of oestrogens, androgens, corticosterone and progesterone was studied during foetal and post-natal development of different animal species (rat, mouse, guinea pig and man). The species studied fall apart into two groups : on one hand rat and mouse in which high concentrations of binding proteins for oestrogens, corticosterone and progesterone are present during foetal life as well as post-natally, on the other hand guinea pig and man in which serum has very little binding capacity for steroids during foetal and post-natal development. In the latter group, however, high amounts of binding proteins are present in the serum of pregnant females.

The results demonstrate a large inter-species variation in hormonal situation during development; moreover, they emphasize the extensive variation with age in serum binding of steroids within a given animal. The biological significance of this steroid binding is discussed in the light of the hypothesis that hormones bound to proteins are provisionally inactive. On the contrary, presence of high amounts of hormones in the blood in the absence of binding protein would implicate high biological activity.

The post-natal period in the rat was studied and is discussed : the protein binding of serum oestrogens, androgens and corticosteroids during this period may be involved in the process of sexual maturation.

\section{INTRODUCTION}

The binding of hormonal steroids by serum proteins in the adult of numerous species have been reported previously (WESTPHAL, I97I; KING and MaINWARING, I974). On the other hand the study of such steroid binding during foetal life and in 
the perinatal period has only recently been initiated (Koch et al., I967; NUNEZ et al., I97I $a, b$; RAYNAUD et al., I97I).

A comparative study of the binding properties of serum proteins in different animal species in the course of development and during gestation may contribute to a clarification of the physiological mechanism of hormone action in this period, in which there is consecutively cellular and sexual differentiation, parturition and sexual maturation.

We will briefly describe here the results obtained in this domain in our laboratory, and attempt to discuss their possible physiological significance.

\section{I. - MATERIAL AND METHODS}

Rat and Mouse. Ch. Rivers CD. The foetal age is given with an approximation of $\pm \mathrm{I}$ day. Blood was collected by cardiac puncture or by decapitation of animals lightly anaesthetised with ether. The serum was after blood collection and centrifugation.

Guinea-Pig of a tri-coloured strain, very kindly furnished by M. AzRIA (Sandoz Laboratory, France). The males and females were left in contact for 4 days. Foetal blood was obtained by cardiac puncture.

Man. Blood was collected from human foetuses of different ages after therapeutic abortions. Sera from pregnant women, in three trimesters of pregnancy, and umbilical cord were furnished by Professor Ph. Engelmann (Lariboisière hospital). Also several sera from hospital patients in whom a hepatoma has been diagnosed have been obtained.

Purified human $\alpha_{1}$-foetoprotein preparations were generously donated by professors HiraI and Nishi (Sapporo, Japan) and Professor MasseyefF (France).

Steroids. The following radioactive steroids were used :

\begin{tabular}{|c|c|c|}
\hline Steroid & Source & $\begin{array}{c}\text { Specific activity } \\
(\mathrm{Ci} / \mathrm{mmole})\end{array}$ \\
\hline Oestrone-6-7- ${ }^{3} \mathrm{H}$ & $\mathrm{CEA}(\mathbf{1})$ & 34 \\
\hline Oestradiol-17 $\beta 6-7-{ }^{3} \mathrm{H}$ & $\operatorname{NEN}\left({ }^{2}\right)$ & 55 \\
\hline Oestriol $-6-7-{ }^{3} \mathrm{H}$ & NEN & 42,2 \\
\hline Testosterone-1-2- ${ }^{3} \mathrm{H}$ & CEA & 42 \\
\hline Corticosterone-1-2-3 $\mathrm{H}$ & CEA & 24 \\
\hline
\end{tabular}

(1) Centre d'Études atomiques.

(2) New England Nuclear.

Crystallized oestrone, I $7 \beta$-oestradiol and oestriol were supplied by Roussel Uclaf. The purity of the steroids was verified by thin-layer chromatography on silicagel using several solvant systems. The radioactive compounds were repurified at regular intervals on celite columns.

I $7 \beta$-oestradiol benzoate- $6-7^{-3} \mathrm{H}$ ( $17 \beta$-hydroxy-I3,5 (Io) oestrien 3 -yl-benzoate) was prepared in the laboratory.

Proteins were measured according to LowRy et al. (1951) using bovine serum albumin as the standard. 
Radioactivity was measured with an Intertechnique Scintillation counter having a 45 p. 100 efficiency.

Treatment of experimental data. Regression lines were calculated according to the S/oog Olivetti Program; speeding of calculations was achieved with the aid of Olivetti Programma and Multi 8 Intertechnique computers.

The affinity of sera or of protein preparations for oestrogens was estimated by the method of Pearlman and CREPY (I967) based on equilibrium dialysis. The $\mathrm{I} / \mathrm{P}(\mathrm{L} / \mathrm{g}$ ) indices, i.e. the inverse of the protein concentration in the dialysis medium for which the free steroid (Su)/bound steroid (Sb) ratio is unity, were thus measured.

Gel filtration on Sephadex G-roo has also been applied for sera pre-incubated with tritiated steroid (NUNEz et al., I97I $a$ ). The results are expressed in picomoles of steroid bound per mg protein.

Determination of binding parameters. The association constant $\mathrm{Ka}$ and the product $\mathrm{n}_{1} \mathrm{M}_{1}$ (number of binding sites $\times$ moles of binding protein) were determined. A variant (SAvU et al., I972) of PEARLMAN and CREPY's equilibrium dialysis method was used. The binding parameters were determined at $25^{\circ} \mathrm{C}$ in a $0.5_{5} \mathrm{M}$ phosphate buffer $\mathrm{pH} 7 \cdot 4$.

\section{Assays}

Serum FSH concentration (ng NIAMD-rat FSH-RP-I/ml) was estimated by a double antibody radioimmunoassay using the kit provided by the National Institute for Arthritis and Metabolic Diseases.

Serum oestrone and oestradiol. Concentrations were measured by radioimmunoassay after extraction of the sera with cyclo hexane-ethyl acetate ( $x: I)$. The extract was evaporated and the residuedissolved in $0.2 \mathrm{ml}$ benzeneethanol (95:5). This was then subjected to chromatography on a $300 \mathrm{mg}$ Sephadex LH 20 microcolumn prepared in benzene-ethanol (95:5). Oestrone was eluted first and then the $17 \beta$-oestradiol was eluted with benzene-ethanol (90:10). The recovery after extraction and separation was calculated by the use of radioactive tracer steroids.

The antibody used for $I_{7}^{\beta}$-oestradiol assay was an anti-oestradiol-6 CMO BSA (Rabbit $\mathrm{L}_{43} 86$ ) (DRAY et al., I97I) and for oestrone assay the Caldwell anti-oestradiol o79r6 was used.

$\alpha_{1}$-foetoprotein (AFP) concentration was determined by the MaNciNi et al. (1965) method using pure anti-rat AFP antibodies prepared in this laboratory.

\section{II. - RESULTS}

\section{I. - Binding with oestrogens and androgens}

We will briefly summarize here, and discuss below, our principal results.

a) Rat.

The serum of rat embryos has a considerable affinity for oestrone and oestradiolI7 $\beta$ (NUNEZ et al., I97I $a, b$ ) (table I). Although this activity diminishes significantly after birth, it is maintained at a very high level for the first days of life, becomes low at the age of $2 \mathrm{I}$ days and disappears after the 28 th day. The serum of pregnant rats, compared on the one hand with that of the embryo and on the other hand with that of the normal adult rat, has a low binding activity. The affinity is significantly higher for oestrone than for $\mathrm{I}_{7} \beta$-oestradiol. The serum studied had no binding affinity for oestriol, despite the latter's phenolic nature. 
TABIE I

Binding of corticosterone, oestradiol-1 $7 \beta$ and oestrone; $A F P$ and FSH concentrations in rat sera during development

The binding of corticosterone is determined by gel filtration on Sephadex G-roo. Binding of oestradiol-I7 $\beta$ and oestrone is evaluated by the method of PEARLMAN and CREPY (I967). AFP and FSH levels are determined by MANCINI's technique (I965) and a double antibody radioimmunoassay with the kit provided by the respectively NIAMDD. The results of are the means of duplicate determinations made on three or four poolsd, of serum (3 to ro) animals for each age.



The main protein responsible for the fixation of the oestrogens has been identified (NunEz et al., I97 I $c$, I973) and purified (CrTTaNova et al., I974) : it is the $\alpha_{1}$-foetoprotein (AFP) (URIEL et al., I972, MASSEYEFF I972). The association constants of this protein for oestrone and oestradiol-I7 $\beta$ are of the order of $I 10^{8} \mathrm{M}^{-1}$ (RAYNAUD et al., I97I; SAvU et al., I972). The association constant for oestrone is slightly higher than that for oestradiol-I7 $\beta$.

The capacity of rat serum to bind testosterone and dihydrotestosterone is low at all ages up to the $2 \mathrm{Ith}$ day after birth. Dihydrotestosterone is bound slightly more than testosterone (NUNEZ et al., I97I $a, b$ ).

b) Mouse.

Embryonic sera have a very high affinity for oestrone and oestradiol-I7 $\beta$ (SAvU et al., I974 a). By the I2th day fixation is high, it is maximal between the I $5^{\text {th }}$ and the 18 th day and then diminishes rapidly such that 3 to 4 days after birth only $\mathrm{I}$ to $3 \mathrm{p}$. Ioo of the maximal activity remains. Practically no oestriol is bound either at $\mathrm{I} 2$ days of embryonic life or in the new born, but significant $\mathrm{I} / \mathrm{P}$ indices, although much lower than those for oestrone and oestradiol-I7 $\beta$, have been measured in the most active sera of $I_{5}$ to $I 8$ day embryos. The sera of pregnant mice bind little oestrogen. However a definite binding is present at $\mathrm{I} 8$ days of pregnancy and above all the day of delivery. The sera of non-pregnant control mice had practically no affinity for the phenolic steroids. In all cases the affinity indices were higher for oestradiol-I7 $\beta$ than for oestrone. The determination of the association 
constants confirmed that oestradiol-I $7 \beta$ is fixed with stronger affinity than oestrone by the foetal oestrogen binding protein of the mouse.

The association constants were $0.30,0.74$ and $0.02 \cdot 10^{8} \mathrm{M}^{-1}$ respectively for oestrone, oestradiol-I $7 \beta$ and oestriol. Here again it is the AFP which is the protein mainly responsible for this fixation (URIEL et al., I972).

c) Guinea-Pig.

The I/P affinity indices for oestradiol and testosterone of foetal and maternal sera at different times of gestation (SAVU et al., I974 b) show that at no point do the serum proteins of the guinea pig present a significant affinity for the oestrogens. In contrast to the pregnant female, in which the serum has a very high binding activity for testosterone, the foetal serum practically does not bind this hormone (MIIGRom et al., I973).

d) Man

Human foetal sera at different ages, the sera of patients with primitive hepatomas containing AFP, and purified preparations of human AFP do not bind oestrogens (NUNEZ et al., I974; SAvU et al., I974 b), unlike those of rat and mouse. It seems that the "Sex Binding Globulin" (MERCIER-BodARD et al., I970) present in the adult and especially in the female during the 3 rd trimester of pregnancy, exists only in small amounts or not at all in the embryo.

\section{2. - Binding with corticosterone and progesterone}

a) Rat.

Our results obtained with corticosterone (NUNEz et al., I97I $b$, SAvU et al., 1973, BENASSAYAG et al., 1974) agree with the reports of others on this subject (KOCH et al., 1967). Serum binding of corticosterone falls rapidly after birth to reach a very low level between the $5^{\text {th }}$ and $5_{5}$ th day, climbs back by the 28 th day to a level which is essentially the same as that of the rat on the Igth day of pregnancy. The difference between our results and those previously published (KocH et al., I967) is that the level of binding in the embryo is higher than that in the mother. Furthermore, the binding of progesterone is different in the embryo and the mother. In the latter the affinity indices for corticosterone and progesterone are virtually the same, while in the embryo the serum fixes five times more corticosterone than progesterone (NuNEz et al., I97 r $b$, SAvU et al., I973).

These results give rise to a number of questions : is the higher binding of corticosterone by embryonic serum, compared with that of the mother, due, as in the case of the oestrogens, to a specific embryonic protein, or is it a matter of a simple quantitative difference concerning the corticosterone binding globulin of the rat (CBG or transcortin), which is, however, well known and characterised?

What is the molecular basis and physiological significance of the absence of binding seen in the rat between the 5 th and the 15 th day? The study of the binding parameters of foetal serum compared with those of the adult female pregnant or not pregnant seems to indicate that the higher levels of fixation of corticosterone in the embryo are due to a quantitative rather than a qualitative difference between 
their binding proteins. The hypothesis of a passage of maternal CBG into the embryo cannot be excluded.

The purification of transcortin extracted from embryonic serum and its comparison with adult transcortin will further clarify these results; such a purification is now under study.

b) Mouse.

The results (SAvU et al., I975) are shown in table 2 and it can be seen that a high affinity for corticosterone is present not only in the serum of the pregnant

TABLE 2

Affinity index for corticosterone and progesterone in fetal and pregnant mouse (table 2) and guinea-pig (table 3) sera

The results are the means of duplicate determinations made on four serum pools for each age according to the PeArlman-Crepy (I967) technique

\begin{tabular}{|c|c|c|}
\hline \multirow{2}{*}{ Mouse } & \multicolumn{2}{|c|}{ Steroïd } \\
\hline & Corticosterone & Progesterone \\
\hline Embryo day 18 & 11 & 3,1 \\
\hline Pregnant female . . & 24 & 10 \\
\hline Female Adult $\ldots \ldots \ldots \ldots$ & 2,4 & 1,6 \\
\hline
\end{tabular}

mice but also in that of the embryos. The $I / P$ indices measured in the latter are 4 to 5 times higher than those of non-pregnant adults, but they remain, however, significantly weaker on average than those determined in maternal sera. The inverse phenomena have been described in the rat. The binding of corticosterone by female mouse serum at different periods after birth shows that the fall in binding after birth is much more rapid than that in the rat. The climb back to the adult level occurs progressively up to the age of 2 I days.

The study of the binding parameters for corticosterone with embryonic and corresponding maternal sera shows that the association constant of the embryoserum is 3-4 times higher than the maternal one.

With regard to progesterone, it can be seen in the mouse that the fixation is higher in foetal than in the maternal sera, while in the rat similar values are found for the foetus and the mother.

Therefore, the foetal transcortin could be qualitatively different from the maternal transcortin. It would then be a matter either of a specific foetal protein or of a structural modification of the maternal transcortin during its possible passage into the foetal serum.

c) Guinea-Pig.

The comparison of the $\mathrm{I} / \mathrm{P}$ indices measured in embryonic and maternal sera at three stages of gestation (SAvU et al., I975) (table 3) shows that the binding activities with regard to the two hormones remain weak in the embryos even on the 
54th day of pregnancy, when the maternal sera are most active. The contrast is particularly marked in the case of progesterone : in the mothers the affinities for this steroid reach values close to Ioo times higher than those in the embryos. Futhermore it can be noted that the low activities found in foetal sera change as a function of the stage of pregnancy in the same direction as the strong activities of the pregnancy sera, which suggests that they are due to the presence of traces of maternal binding protein (MILGROM et al., I973).

TABLE 3

\begin{tabular}{r|c}
\hline \\
Cituinea-pig \\
Embryo day $37 \ldots \ldots \ldots \ldots \ldots \ldots$ \\
Embryo day $54 \ldots \ldots \ldots \ldots \ldots \ldots$
\end{tabular}

d) Man.

This study (SAvu and NunEz, unpublished) is being undertaken in our laboratory at present. The results obtained so far show that the fixation of corticosterone by CBG is low in the embryo up to the 5 th month, while the level in the mother increases in a regular fashion.

\section{III. - DISCUSSION ON THE BIOLOGICAL SIGNIFICANCE} OF STEROID BINDING

Studies on steroid binding by serum protein during foetal and post-natal development by NuNEz et al. (I97I $a, b, c$, I974), RAYNAUD et al. (I97I), SAvU et al. (1973, I974 $a, b$ ), BENASSAYAG et al. (1974) revealed a contrast between two groups of mammalian species. On the one hand, rat and mouse, which present large amounts of proteins binding oestrogens, corticosterone and progesterone during foetal life and after birth; on the other hand guinea-pig and man, in which sera do not bind the same steroids or, if so, only weakly. However the pregnant females of the last species have high levels of steroid binding proteins.

These facts underline the great disparity between the hormonal mechanism and the regulation of sexual maturation in different animals. Furthermore, the binding properties of steroid-binding proteins show great variation with time in a single species. It is therefore interesting to specify such possible fluctuations for 
each type of animal in order to correlate these variations with those presented by other biological parameters in the same period. In this way, it will be possible to have some idea of the particular physiological significance of a hormone-binding protein at a given period and for a given species. This may be totally different in other circumstances.

From recent studies (RAynaud, 1973; Meijs-Roelofs et al., I973; ThalerDAO and BREUER, 1974) a hypothesis about the part played by protein-steroid binding emerges. This binding of steroid hormones may completely supress the hormonal action or modulate it. This modulation depends in a large part on the relative affinity for the hormone of its binding serum protein and its target receptor. This situation provokes, according to the case, a more or less selective distribution of the steroid to the tissues.

It is probably in the hypothalamo-hypophysial-gonadial regulation that rat and mouse foetoproteins, but also transcortins, could intervene by regulating the hormonal level. As far as the rat is concerned, the work of MEIJS-ROELOFs et al. (I973) confirmed by BROWN-GRANT (I974) suggests that the seemingly paradoxical coexistence in the female rat after birth of both increased secretion of FSH and of high levels of oestrogen could be due to the strong affinity of $\alpha_{1}$-foetoprotein (AFP) for estrogens (NUNEZ et al., I97 I c). It seems that this strong binding between foetoprotein and oestrogens causes a strong but incomplete inhibition (FSH secretion can be enhanced by ovariectomy (MEIJS-RoELOFS et al., I973) of the negative feed-back action of oestrogens on gonadotrophin secretion. On the contrary, the low binding associated with high hormone levels in the blood should lead to strong biological activity. On the same lines, we suggest that the lower LH levels in male rats (BROWN-GRANT, I974) during the same period are the result of the total lack of serum affinity towards androgens (NuNEz et al., I97 I b).

On the basis of these results, we undertook the simultaneous assay of FSH, oestrogens and AFP during the post-natal period in rat. The results obtained (table $\mathrm{r}$ ), compared with the fixation of oestrogens and corticosterone to the serum proteins (BENASSAYag et al., I974) during this period, entirely confirm the results of Meijs-Roelofs et al. (I973) and Brown-Grant (1974). The AFP concentration, and the binding of oestradiol and oestrone are marked when the FSH, oestradiol and oestrone levels are high. FSH decay is parallel to that of AFP (VALIETTE et al. unpublished).

A comparative study (VALLETTE et al., unpublished data) of the AFP levels in the male and the female shows that the evolution of these levels is strictly parallel in both sexes. AFP concentration is slightly lower in the male. Moreover, oestrone is the predominating hormone during development. We found values five to fifteen times higher for oestrone than oestradiol $(66 \mathrm{pg} / \mathrm{ml}$ oestradiol-I7 $\beta$ and I $093 \mathrm{pg} / \mathrm{ml}$ oestrone in the I7 day old embryo; $34 \mathrm{pg} / \mathrm{ml}$ oestradiol-I $7 \beta$ and $200 \mathrm{pg} / \mathrm{ml}$ oestrone in the 3 day old female rat).

This has also been observed by WEISz and Gunsalus, I973 and can be explained by a slightly higher affinity of AFP for oestrone than for oestradiol (NUNEZ et al., I97I $b$, RAYNAUD et al., I97I, SAvu et al., 1972) and/or by a particular metabolic situation. The relative affinity of AFP for the various oestrogenic hormones could have a biological significance. Thus some oestrogenic compounds which are less bound to the AFP could completely or in part escape the "inactivation by bin- 
ding ". To study this, we have tested (SAvU and NUNEZ, unpublished data) the binding of oestradiol benzoate (I $\beta$-hydroxy-I, 3, 5 (IO) oestratrien-3 yl-benzoate), an oestrogen often used by physiologists, in embryonic and immature female rat sera. This oestradiol conjugate is bound to a significant but lower level than oestrone or oestradiol-I 7 . The affinity indices are respectively 45 for oestradiol-I $7 \beta$ and 28 for oestradiol benzoate in the 4 day old female serum.

In conclusion there does seem to be an intriguing correlation between the AFP concentration and the "paradoxical phenomena " described by MEIJs-RoELOFs et al. (I973). This can only be definitively proven when, by induction of changes in AFP concentration, the FSH concentration is made to vary. Futhermore the study of the transcortin-corticosterone binding during this same period may give us a more complete explanation of the complex hormonal phenomena that are taking place in this period.

In effect, we have confirmed (NUNEz et al., I97 I $b$; BENASSAYAg et al., I974) that between the 5 th and $55^{\text {th }}$. day there is a period in which the binding of corticostrone is very low while the free corticosterone concentration is increased (KoCH et al., I 967 ). Thus the corticosterone which is in a free state can act on the hypothalamo-hypophysial-adrenal axis and exert a negative feed-back effect.

It seems that these facts may be integrated with the results on oestrogen and androgen levels into an overall schema which would permit a better understanding of the hormonal factors involved in sexual maturation of the rat.

Sexual Maturation, 3 rd Workshop August 31, September 3, 1975.

\section{ACKNOWLEDGEMENTS}

This work was supported by D.G.R.S.T. no 72.7 .0574 ; A.T.P.-I.N.S.E.R.M. no $72 . I .486 .12$ and 74.5.004. OI grants and an allocation from the "Fondation pour la Recherche Medicale".

\section{RÉSUMÉ}

FIXATION SÉRIQUE DE QUELQUES HORMONES STÉROÏDES

AU COURS DU DÉVELOPPEMENT DE DIVERSES ESPÈCES ANIMALES. DISCUSSION SUR IA SIGNIFICATION BIOLOGIQUE DE CETTE FIXATION

La fixation des oestrogènes, des androgènes, de la corticostérone et de la progestérone est étudiée chez différentes espèces animales (Rat, Souris, Cobaye et Homme) au cours de la vie fœtale et post-natale.

Cette étude nous permet de distinguer parmi les espèces étudiées, d'une part le Rat et la Souris qui présentent en abondance des protéines liant les oestrogènes, la corticostérone et la progestérone au cours de la vie fœetale et après la naissance, d'autre part le Cobaye et l'Homme dont les sérums lient peu ou pas les stéroïdes au cours de leurs développements fotal et post-natal. Par contraste, les sérums des femelles gestantes de ces derniers sont riches en protéines liantes.

Ces résultats montrent la grande diversité des schémas hormonaux du développement d'une espèce à l'autre ils soulignent la très grande variabilité des phénomènes de fixation sérique des hormones au cours du temps chez un même animal. Le rôle biologique de ces liaisons est discuté 
à la lumière de l'hypothèse selon laquelle l'hormone liée aux proteines sériques est provisoirement inactive. L'absence de protéine de liaison alors que l'hormonémie est élevée impliquerait au contraire une activité biologique.

Nous avons choisi comme modèle de discussion et d'expérimentation la période post-natale du Rat où la liaison proteine sériques-œstrogènes, androgènes et corticoïdes jouerait un certain rôle dans le déterminisme hormonal de la maturation sexuelle.

\section{REFERENCES}

Benassayag G., Engrlmani F., Vallette G., Nunez E., Jayle M. F., Terolem A., I974. Fixation de l'œestradiol $17 \beta$ par certains tissus du Rat au cours du développement. $43 \mathrm{I}-444$. Colloquittm on $\alpha$-foetoprotein, I.N.S.E.R.M.Paris.

Brown-Grant K., I974. On " critical Periods " during the post-natal developnent of the rat. in Symposium on Perinatal Sexual Endocrinology. I.N.S.E.R.M. Paris.

Cittanova N., Grigorova A. M.., Benassayag C., Nunez E., Jayle M. F., i974. Affinity chromatography purification of rat $\alpha_{1}$-fœtoprotein. Febs Letters, 41, $21-24$.

Dray F., Tergui M., Desfosses B., Chauffournier J. M., Mowskowicz I., hahi D., Rombavts P., JAYle M. F., I97I. Propriétés d'immunsérums anti I $7 \beta$-œestradiol obtenus chez différentes espèces animales avec l'antigène $I 7 \beta$-cestradiol-6-0-carboxy methoximeserum albumine de bøuf, $C . R . A c a d$. Sc. Paris, D, 273, $2380-2383$.

King R. J. B., Mainwaring W. P., 1974. Steroid-Cell Interactions. Butterworths. London.

Косн B., Miahle-Voloss C., Stutinsky F., ig67. Fraction liée et libre de la corticosterone plasmatique au cours du développement post-natal chez le Rat. C. R. Acad. Sc. Paris, D, 264, I I83-I I86.

Lowry G. H., Rosenbourg N. J., Farr A. L., Randal R. J., I951. Protein measurement with the Folin phenol reagent. J. Biol. Chem., 198, 265-276.

Mancini G., Carbonara A. O., Heremans J. F., r965. Immunochemical quantitation of antigens by single radial immunodiffusion. Immunochemistry, 2, 235-254.

MasseyefF R., I972. Human Alpha-Foto-Protein (a review). Path. Biol., 20, 703-725.

Meijs-Roelofs H. M. A., Uilenbroek J. TH. J., De Jong F. H., Welschen R., ig73. Plasma oestradiol-r $7 \beta$ and its relationship to serum follicule stimulating hormone in immature fenale rats. $J$. Endocr., 59, 295-304.

Mercier-Bodard C., Alfsen A., Bauliev E. E., I97o. Sex Steroid Binding Plasma Protein SBP. Acta Endocr. (Kbh), Suppl. 147, 204-224.

Milgrom E., Allouch P., Atger M., Baulieu E. E., r973. Progesterone-binding plasma protein of pregnant guinea-pig. J. Biol. Chem., 248, I IO6-I I I4.

Nunez E. A., Engelmann F., Benassayag C., Sayu L., Crepy O., Jayle M. F., I97I a. Mise en évidence d'une fraction protéique liant les oestrogènes dans le sérum de rats impubères. $C$. $R$, Acad. Sc. Paris, D, 272, 2396-2399.

Nunez E. A., Savu L., Engelmann F., Benassayag C., CRepy O., Jayle M. F., I97i $b$. Origine embryonnaire de la protéine sérique fixant l'cestrone et l'œstradiol chez la Ratte impubère. $C$. $R$. Acad. Sc., Paris, D, 273, 242-245.

Nunez E. A., Engelmann f., Benassayag C., Jayle M. F., I97I c. Identification et purification préliminaire de la foetoprotéine liant les ostrogènes dans le sérum de rats nouveaux-nés. $C$. $R$. Acad. Sc. Paris, D, 273, $831-834$.

Nunez E. A., Benassayag C., Engelmann F., Vallette G., Hurst L., Jayle M. F., 1973. Binding of cestrogens to serum of rats treated with hepatocarcinogenic compounds. Biomédecine, 18, 5I4-520.

Nunez E. A., Vallette G., Benassayag C., Jayle M. F., I974. Comparative study on the biinding of cstrogens by human and rat serum protein in development. Biochim. Biophys. Res. Comm., 57, I26-I33.

Pearlman W. H., CREPY O., 1967. Steroid-Protein interaction with particular reference to testosterone binding by human serum. J. Biol. Chem., 242, I 28-189.

Raynaud J. P., Mercier-Bodard C., Baulieu E. E., I97I. Rat estradiol binding plasma protein. Steroids, 18, 767-787.

RAYNAUD J. P. I973. Influence of rat estradiol binding plasma protein (EBP) on uterotrophic activity. Steroids, 21, 249-258.

Savu L., Crepy O., Guerin M. A., Nunez E. A., Engelmann F., Benassayag C., Jayle M. F., 1972. Étude des constantes de liaison entre les oestrogenes et l' $\alpha_{1}$-foetoprotéine de rat. Febs Letters, 22, II3-II5.

Savu L., Crepy O., Nunez E., Jayle M. F., 1973. Affinité comparée des sérums embryonnaires et maternels pour la corticostérone et la progestérone chez le Rat. Fur. J. Biochem., 35, 464-47o. 
Savu L., Nunez E., Jayle M. F., rg74a. Haute affinité du sérum d'embryon de souris pour les œstrogènes. Biochem. Biophys., 359, 273-28I.

Sayu L., Vallette G., Nunez E. A., Azria M., Jayle M. F., r974 $b$. Étude comparative de la liaison entre les protéines sériques et les ostrogèns libres au cours du développement de diverses espèces animales, 75-83. Colloquium on $\alpha-F$ ceto-Protein, I.N.S.E.R.M. Paris.

Thaler-Dao H., BREUer H., I974. Gonadal factors regulating the activity of the I7 $\beta$-hydroxysteroid oxydoreductase in rat liver. Acta Endocy., 77, 727-723.

Uriel J., de Nechaud B., Dupiers M., 1972. Estrogen-binding properties of rat, mouse and man fœto-specific serum proteins. Demonstration by immunoautoradiographic methods, Biochem. Biophys. Res. Comm., 46, I $175-1$ I 80 .

Weisz. J., Gunsalus P., r973. Estrogen levels in immature female rats. True or spurious-ovarian or adrenal? Endocrinology, 98, 1057-1065.

WestPhal U., I97I. Steroid-Protein Interactions. Monographs on Endocrinology. Springer Verlag. 